\title{
Pengaruh Pupuk Nitrogen dan Ethephon terhadap Pertumbuhan, Pembungaan dan Hasil Padi Lokal (Oryza sativa L. cv. Rojolele)
}

\author{
Effects of Nitrogen Fertilizer and Ethephon on Growth, Flowering and Yield of Local Rice \\ (Oryza sativa L. cv. Rojolele)
}

\author{
Diah Rachmawati*, Maryani dan Tri Setyaningsih \\ Fakultas Biologi, Universitas Gadjah Mada \\ Jalan Teknika Selatan Sekip Utara Yogyakarta 55281 \\ E-mail: rbudiharjo@yahoo.com*Penulis untuk korespondensi
}

\begin{abstract}
Physiological studies on Rojolele rice were conducted after the application of nitrogen fertilizer and ethephon at different doses. Application of nitrogen fertilizer is one of the most important measurements to improve plant growth and yield of rice. Ethylene which has flowering initiate roles are induced by ethephon. The objective of this study was to analyze the effect of nitrogen fertilizer and ethephon on growth, flowering and yield of rice (Oryza sativa L. cv. Rojolele). The experiment was carried out using Complete Randomized Design with 2 factors, which each factor consisted of four levels. The first factor was doses of urea as nitrogen source $0,50,100$ and $150 \mathrm{~kg} \mathrm{ha}^{-1}$. The second factor was doses of ethephon 0; 100; 200 and $400 \mathrm{mg} \mathrm{l}^{-1}$. Measured parameters were plant height, tiller number, plant biomass, root shoot ratio, flowering time, yield and grain size. The application of nitrogen fertilizer improved the plant growth of Rojolele rice. Plant height, tiller number, plant biomass, panicle length, and number of grains increased by the increasing doses of nitrogen, but this factor did not significantly affect on grain size. Ethephon application reduced plant height and delayed flowering time. However, it simultaneously increased tillers when compared at the same $\mathbf{N}$ dose. Interaction between nitrogen fertilizer and ethephon gave significantly effects on the plant height and number of grains per panicle, but there were no significant effect on the rice grain size.
\end{abstract}

Key words: Oryza sativa L. cv. Rojolele, nitrogen fertilizer, ethephon, growth, flowering

\begin{abstract}
Abstrak
Kajian fisiologi padi Rojolele dilakukan setelah aplikasi pupuk nitrogen dan ethephon pada dosis yang berbeda. Aplikasi pupuk nitrogen merupakan salah satu upaya yang penting untuk meningkatkan pertumbuhan dan hasil panen padi. Etilen yang berperan memacu pembungaan diinduksi oleh ethephon. Tujuan penelitian ini adalah menganalisis pengaruh pupuk nitrogen dan ethephon terhadap pertumbuhan, pembungaan dan hasil panen padi (Oryza sativa L. cv. Rojolele). Percobaan dilakukan menggunakan Rancangan Acak Lengkap dengan 2 faktor, yang masing-masing faktor terdiri dari empat aras. Faktor pertama adalah dosis urea sebagai sumber nitrogen 0, 50, 100 dan $150 \mathrm{~kg} \mathrm{ha}^{-1}$. Faktor kedua adalah dosis ethephon 0, 100, 200 dan $400 \mathrm{mg} \mathrm{l}^{-1}$. Parameter yang diukur meliputi tinggi tanaman, jumlah anakan, biomassa tanaman, rasio pucuk akar, waktu berbunga, hasil panen dan ukuran biji. Aplikasi pupuk nitrogen meningkatkan pertumbuhan tanaman padi rojolele. Tinggi tanaman, jumlah anakan, biomassa tanaman, panjang malai, dan jumlah gabah meningkat dengan meningkatnya dosis nitrogen tetapi faktor ini tidak secara signifikan mempengaruhi ukuran biji. Aplikasi ethephon mengurangi tinggi tanaman dan menunda waktu berbunga. Namun, secara bersamaan meningkatkan jumlah anakan jika dibandingkan pada dosis $\mathbf{N}$ yang sama. Interaksi antara pupuk nitrogen dan ethephon secara signifikan berpengaruh pada tinggi tanaman dan jumlah gabah per malai, tetapi tidak berpengaruh signifikan terhadap ukuran biji.
\end{abstract}

Key words: Oryza sativa L. cv. Rojolele, pupuk nitrogen, ethephon, pertumbuhan, pembungaan 


\section{Pendahuluan}

Di Indonesia beras memiliki arti penting antara lain sebagai makanan pokok penduduk. Padi rojolele (Oryza sativa L. cv. Rojolele) merupakan salah satu padi lokal aromatik yang mempunyai nilai ekonomis tinggi. Padi sawah lokal rojolele ditetapkan sebagai varietas unggul berdasarkan SK Menteri Pertanian Nomor: 126/Kpts/TP.240/2/2003. Padi rojolele memiliki keunggulan antara lain rasa nasi yang enak dan pulen, tetapi memiliki umur panen panjang yaitu 155 hari sejak sebar (HSS). Karena umur panen yang panjang tersebut, budidaya padi rojolele kurang diminati oleh petani. Informasi mengenai faktor yang berpengaruh terhadap pertumbuhan padi rojolele masih terbatas. Oleh karena itu, perlu dilakukan upaya untuk mengkaji lebih lanjut sifat fisiologi tanaman padi untuk meningkatkan sifat unggulnya, dengan cara memperpendek masa vegetatif dan mempercepat waktu pembungaannya.

Aplikasi senyawa pengatur tumbuh dan unsur hara dapat digunakan untuk manipulasi pertumbuhan dan meningkatkan produktivitas tanaman (Atmodjo, 2000). Beberapa senyawa kimia, seperti phosphon-D, paklobutrazol, chlormequat chloride, AMO 1618, dan ethephon termasuk dalam kelompok senyawa pengatur pertumbuhan yang bersifat menghambat (growth retardant). Aplikasi growth retardant pada tanaman pangan dan hortikultura untuk menurunkan pertumbuhan tunas yang tidak diinginkan tanpa menurunkan produktivitas tanaman (Rademacher, 2000). Tripathi et al., (2003) melaporkan, aplikasi ethephon (2-chloro ethyl phosphonic acid) atau CCC (chlormequat chloride) berperan dalam menurunkan tinggi tanaman dan selanjutnya mengurangi indeks kerebahan.

Diketahui bahwa aplikasi growth retardant dapat menekan pertumbuhan vegetatif dan memacu pembentukan bunga. Namun, pengaruh senyawa pengatur pertumbuhan juga tergantung banyak faktor lain, seperti jenis atau kultivar tanaman, konsentrasi yang digunakan, cara aplikasi, dan saat aplikasi (Davies, 1995). Rajala dan Peltonen-Sainio (2001) mengemukakan bahwa aplikasi growth retardant pada tanaman serealia mengakibatkan peningkatan pertumbuhan akar dan atau rasio akar/tajuk.
Akan tetapi, pengaruhnya pada hasil belum konsisten. Menurut Woodward dan Marshall (1987) aplikasi senyawa pengatur tumbuh tahap awal pertumbuhan berpengaruh pada jumlah anakan. Pengaruh ethephon, CCC, dan mepiquat klorida, sendiri atau kombinasinya dapat memacu pembentukan anakan dan meningkatkan jumlah kuncup anakan. Peningkatan pembentukan anakan disebabkan perubahan kepekaan terhadap panjang hari, hambatan biosintesis dan transpor auksin yang menginisiasi dominansi apikal atau perubahan asimilat dan ketersediaan nutrien.

Ketersediaan hara yang optimal memberikan kontribusi pada pertumbuhan tanaman dan hasil panen. Unsur hara nitrogen, fosfor, dan kalium merupakan faktor pembatas utama untuk produktivitas padi (Setyorini dan Abdulrachman, 2008). Unsur nitrogen berperan penting dalam pertumbuhan dan perkembangan tanaman. Nitrogen merupakan komponen struktural dari protein, asam nukleat, klorofil dan senyawa pengatur tumbuh yang berperan penting untuk pertumbuhan dan perkembangan tanaman (Below, 2002; Barker dan Pilbeam, 2007; Mangunwardoyo et al., 2009). Oleh karena itu, pemberian pupuk nitrogen yang tepat sangat penting untuk meningkatkan pertumbuhan dan hasil tanaman. Kekurangan nitrogen atau pengelolaan nitrogen yang tidak sesuai akan berakibat buruk pada tanaman dan lingkungan. Strategi pengelolaan nitrogen yang optimal ditujukan pada keserasian pemberian pupuk nitrogen dengan kebutuhan aktual tanaman, sehingga serapan tanaman terhadap nitrogen maksimal dengan mengurangi kehilangan nitrogen ke udara.

Penggunaan pupuk yang tepat secara nyata dapat meningkatkan hasil dan memperbaiki kualitas gabah. Jenis pupuk nitrogen juga dapat mempengaruhi hasil dan kualitas gabah (Chaturvedi, 2005). Pupuk urea secara substansial mempunyai kandungan $\mathrm{N}$ yang lebih tinggi daripada yang lain (Barker dan Pilbeam, 2007). Mengingat pentingnya pemupukan nitrogen terhadap hasil gabah tanaman padi, maka perlu diketahui dosis yang terbaik untuk tiap-tiap varietas maupun faktor-faktor yang mempengaruhi komponen hasil untuk mendapatkan pengetahuan yang lebih baik tentang respons terhadap pertumbuhan maupun produksi padi lokal rojolele. 
Uraian di atas menunjukkan bahwa nitrogen sebagai salah satu unsur hara yang dibutuhkan tanaman karena perannya memacu pertumbuhan vegetatif. Namun, kebutuhan nitrogen untuk tumbuhan sangat bervariasi tergantung pada spesies tanaman, tingkat perkembangan dan jenis organ. Oleh karena itu, perlu diteliti pada konsentrasi nitrogen yang diperlukan untuk pertumbuhan optimal tanaman mengingat penelitian tentang padi lokal rojolele sangat terbatas. Aplikasi ethephon mempunyai potensi untuk memperbaiki sistem perakaran dan meningkatkan ketahanan rebah tanaman. Pertumbuhan akar yang kuat akan meningkatkan ketahanan tanaman terhadap rebah dan selanjutnya dapat meningkatkan produktivitas tanaman (Tripathi et al., 2003). Dalam upaya meningkatkan produktivitas tanaman padi lokal rojolele maka dilakukan penelitian yang bertujuan menganalisis pengaruh pupuk nitrogen dan senyawa pengatur tumbuh ethephon terhadap pertumbuhan, pembungaan, dan hasil panen padi lokal rojolele. Dari penelitian ini diharapkan dapat memberi informasi tentang peran nutrien dan senyawa pengatur tumbuh untuk memperbaiki pertumbuhan vegetatif dan melestarikan plasma nutfah yang mempunyai nilai ekonomis tinggi.

\section{Metode Penelitian}

Penelitian dilakukan di rumah kaca Kebun Pendidikan, Penelitian dan Pengembangan Pertanian (KP4) UGM Kalitirto, Berbah, Sleman, Yogyakarta. Percobaan menggunakan rancangan acak lengkap (Complete Randomized Design) dengan dua faktor yaitu pupuk nitrogen dan ethephon. Dosis pupuk nitrogen (urea) terdiri atas 4 tingkat, yaitu $\mathrm{N} 0=$ tanpa pupuk (kontrol), N1= $50 \mathrm{~kg} \mathrm{ha}^{-1}, \mathrm{~N} 2=100 \mathrm{~kg} \mathrm{ha}^{-1}$ dan $\mathrm{N} 3=150 \mathrm{~kg} \mathrm{ha}^{-1}$. Dosis ethephon terdiri atas 4 tingkat, yaitu $\mathrm{E} 0=$ kontrol, $\mathrm{E} 1=100 \mathrm{mg} \mathrm{l}^{-1}, \mathrm{E} 2=$ $200 \mathrm{mg} \mathrm{l}^{-1}$, dan E3= $400 \mathrm{mg} \mathrm{l}^{-1}$. Tiap-tiap kombinasi perlakuan dibuat 5 ulangan.

\section{Bahan dan Alat}

Bahan yang digunakan meliputi benih padi lokal rojolele dari Badan Pengkajian Teknologi Pertanian Yogyakarta, tanah sawah, pupuk organik "fine compost", pupuk urea, pupuk SP36\% dan pupuk $\mathrm{KCl} 60 \%$ serta zat pengatur tumbuh ethrel yang mengandung bahan aktif ethephon $480 \mathrm{~g} / \mathrm{l}$ (Ethrel 40 PGR, Bayer, Indonesia).

Alat yang digunakan dalam penelitian ini yaitu meteran, timbangan analitik, penyaring tanah, pot plastik berdiameter $23 \mathrm{~cm}$, alat penyemprot (sprayer), gunting, amplop kertas, oven, timbangan semi analitik, kamera, jangka sorong, tabung reaksi, gelas beker, pipet ukur, pipette pump, cuvet, mortar dan pestle, spektrofotometer.

\section{Cara Kerja}

Biji padi dipilih yang baik untuk dijadikan benih, yaitu dengan cara dimasukkan dalam air. Biji yang terapung dipisahkan (dibuang) dan biji yang tenggelam direndam dalam air selama \pm 24 jam. Setelah itu, biji dikecambahkan di atas kapas yang dibasahi air dan setelah keluar mata tunas, dipindahkan ke media pembenihan berupa tanah yang dibasahi air. Setelah bibit berumur 14 hari, bibit siap dipindahkan ke dalam pot yang berisi $5 \mathrm{~kg}$ tanah sawah dan pada tiap-tiap pot ditanam satu tanaman.

Perlakuan nitrogen diberikan dalam bentuk pupuk urea dan perlakuan ethephon menggunakan ethrel. Perlakuan pemupukan nitrogen (urea) sebanyak 2 kali. Pemupukan pertama dilakukan satu hari sebelum penanaman sebanyak $1 / 2$ bagian pupuk N. Pemupukan kedua yaitu pemberian $1 / 2$ bagian pupuk $\mathrm{N}$ dilakukan 4 minggu setelah pemupukan pertama. Pemberian ethephon sesuai dosis $50 \mathrm{ml}$ untuk tiap tanaman dengan cara penyemprotan yang dilakukan pada hari ke-75 setelah tanam (HST).

Parameter pertumbuhan yang diamati meliputi tinggi tanaman, jumlah daun, jumlah anakan dan biomassa tanaman (berat segar dan berat kering tajuk dan akar), rasio akar tajuk, kadar klorofil, umur berbunga, panjang malai, hasil gabah, ukuran dan bentuk gabah. Tinggi tanaman diukur dari permukaan tanah sampai ujung daun tertinggi. Jumlah anakan dihitung berdasarkan jumlah anakan yang terbentuk pada tiap tanaman. Berat segar tajuk ditimbang segera setelah tanaman dipotong yaitu mulai dari batang di atas permukaan tanah dan dipisahkan dari akarnya. Berat kering tajuk atau akar ditimbang setelah dikeringkan terlebih dahulu dalam oven selama 2 hari, ditimbang sampai beratnya 
konstan. Waktu pembungaan dihitung sejak bunga pertama kali keluar untuk masing-masing perlakuan. Panjang dan lebar gabah adalah ukuran gabah pada dimensi terbesarnya. Adapun bentuk gabah dilihat dari rasio panjang terhadap lebar gabah (Graham, 2002).

\section{Analisis Data}

Data dianalisis dengan Analisis Variansi (ANAVA) untuk mengetahui adanya beda nyata dan dilanjutkan dengan Duncan Multiple Range Test (DMRT) pada taraf signifikansi 5\% untuk mengetahui beda antarperlakuan (Gomez dan Gomez, 1984). Data disajikan dalam bentuk tabel dan gambar.

\section{Hasil dan Pembahasan}

\section{Pertumbuhan Tanaman}

Pengamatan respon fisiologi tanaman padi rojolele dilakukan setelah aplikasi pupuk nitrogen dan ethephon pada dosis yang berbeda. Pemberian nitrogen untuk memacu pertumbuhan vegetatif tanaman. Ethephon mempunyai potensi untuk memperbaiki sistem perakaran dan meningkatkan ketahanan rebah. Pemberian pupuk nitrogen dan ethephon pada konsentrasi yang berbeda menunjukkan perbedaan pada tinggi tanaman, jumlah daun, dan jumlah anakan dibandingkan dengan kontrol (Gambar 1 dan Tabel 1). Perbedaan tinggi tanaman, jumlah daun, dan jumlah anakan menunjukkan bahwa diperlukan penambahan pupuk nitrogen untuk memacu pertumbuhan tinggi tanaman dan meningkatkan jumlah anakan. Urea adalah pupuk nitrogen yang paling banyak digunakan. Setelah aplikasi, urea diubah menjadi amonia, yang dapat berada di tanah atau dikonversi menjadi nitrat. Selanjutnya nitrat akan diserap oleh tanaman. Nitrat merupakan bentuk yang mudah diserap oleh tanaman (Below, 2002).

Pertumbuhan tanaman berkaitan erat dengan hara yang diserap dari dalam tanah. Ketersediaan hara yang optimal memberikan kontribusi pada pertumbuhan tanaman (Below, 2002; Chaturvedi, 2005; Utami, 2005). Pemberian pupuk nitrogen yang tepat meningkatkan pertumbuhan tanaman padi rojolele. Pada beberapa parameter pertumbuhan seperti tinggi tanaman, jumlah daun, jumlah anakan, dan biomassa tanaman (berat tajuk dan berat akar) meningkat sejalan dengan bertambahnya konsentrasi nitrogen yang diberikan. Pada perlakuan konsentrasi nitrogen yang sama, semakin tinggi konsentrasi ethephon ada kecenderungan tinggi tanaman menurun (Tabel 1). Peningkatan tinggi tanaman sebagai respons terhadap penggunaan pupuk $\mathrm{N}$, karena meningkatnya ketersediaan nitrogen yang akan meningkatkan luas daun sehingga dihasilkan fotoasimilat lebih tinggi, dengan demikian akumulasi bahan kering menjadi lebih banyak.

Hasil penelitian menunjukkan bahwa jumlah anakan padi lokal rojolele meningkat seiring dengan meningkatnya dosis pupuk nitrogen. Hal yang sama juga dilaporkan Chaturvedi (2005), meningkatnya jumlah nitrogen yang diserap menunjukkan peningkatan jumlah anakan per meter persegi. Jumlah anakan pada tanaman padi digunakan sebagai parameter penentu produktivitas, terutama jumlah anakan produktif yang dapat menghasilkan malai. Peningkatan jumlah anakan disebabkan oleh meningkatnya serapan nitrogen selama fase vegetatif dan terkonsentrasinya $\mathrm{N}-\mathrm{NH}_{4}$ disekitar akar (De Datta, 1981). Selain itu, peningkatan pembentukan anakan juga karena fotoasimilat berkaitan dengan ketersediaan unsur hara nitrogen. Nitrogen diperlukan untuk sintesis klorofil, protein dan senyawa organik lainnya (Barker dan Pilbeam, 2007). Dengan demikian, nitrogen berpengaruh terhadap fotosintesis dalam sintesis klorofil dan enzim fotosintetik sehingga berpengaruh pada fotosintat yang terbentuk, yang selanjutnya berpengaruh pada pertumbuhan tinggi tanaman, jumlah daun dan jumlah anakan. Pada perlakuan ethephon memperlihatkan peningkatan jumlah anakan. Hal ini sejalan dengan hasil penelitian Woodward dan Marshall (1987), aplikasi senyawa pengatur tumbuh ethephon, CCC dan mepiquat chloride, sendiri-sendiri atau kombinasinya dapat memacu pembentukan anakan dan meningkatkan jumlah kuncup anakan. Pada tanaman, ethephon akan menghasilkan etilen. Etilen adalah inhibitor nitrifikasi (Arshad dan Frankenberger, 2002) yang membatasi oksidasi $\mathrm{NH}_{4}{ }^{+}$menjadi $\mathrm{NO}_{3}{ }^{-}$, selanjutnya etilen merangsang pertumbuhan akar, anakan dan malai (Hazarika dan Sarkar, 1996).

Perlakuan ethephon juga berpengaruh pada tinggi tanaman, terlihat dosis ethephon 
yang tinggi menghambat pertumbuhan tinggi tanaman. Hal ini karena aplikasi ethrel yang mengandung bahan aktif ethephon pada tanaman menghasilkan etilen. Etilen ini akan mengurangi kemampuan auksin tanaman untuk memacu pertumbuhan batang dan menyebabkan tanaman menjadi lebih pendek (Tripathi et al., 2003). Terhambatnya pertambahan tinggi tanaman padi dengan pemberian ethephon dosis tertinggi (400 $\mathrm{mg} / \mathrm{L})$ karena ethephon sebagai sumber etilen. Ethephon akan mengalami dekomposisi pada $\mathrm{pH}$ fisiologis dan akan melepaskan etilen pada jaringan tanaman, sedangkan pada $\mathrm{pH}$ asam ethephon akan tetap stabil (Srivastava, 2001). Selanjutnya dijelaskan bahwa $\mathrm{pH}$ sitoplasma sel tanaman pada umumnya lebih besar daripada 4 . Maka jika ethephon masuk ke dalam jaringan tanaman, derajat kemasamannya akan turun dan terjadi dekomposisi yang akan melepaskan etilen pada jaringan tanaman. Straub (1989) menyebutkan bahwa ethephon sebagai pengatur tumbuh yang efektif untuk mengurangi tinggi tanaman pada beberapa jagung manis hibrida. Hasil penelitian Tripathi et al., (2003) menyebutkan, aplikasi ethephon menurunkan tinggi tanaman, hasil gabah dan indeks panen, meskipun mampu meningkatkan ketahanan rebah tanaman gandum. Akibat pemanjangan batang terhambat, batang menjadi lebih tebal karena pembentangan sel ke samping lebih terpacu. Dari penelitian ini juga diketahui ketebalan jaringan antara epidermis dan lapisan sel terdalam yang berbatasan dengan ruang udara menunjukkan ada kecenderungan meningkat dengan peningkatan konsentrasi nitrogen dan ethephon yang diberikan. Hasil ini sejalan dengan penelitian Tripathi et al., (2003) aplikasi ethephon meningkatkan ketebalan dinding batang pada internodus ke-1, ke-2, dan ke-3.

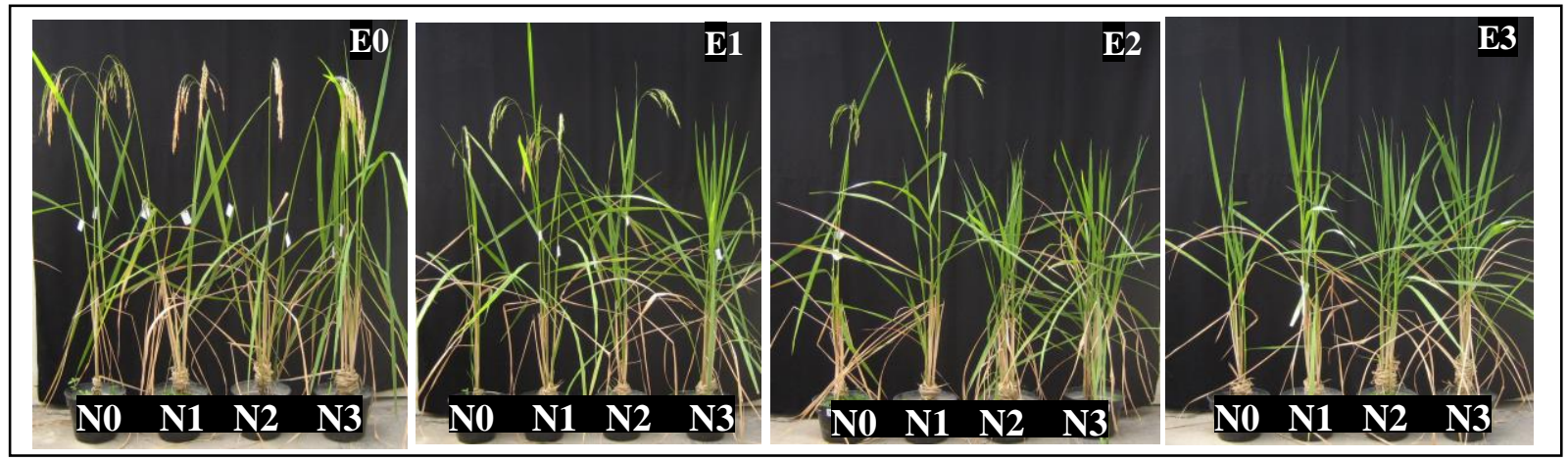

Gambar 1. Kenampakan morfologi tanaman padi rojolele umur 125 hari. N0: kontrol (tanpa pupuk N); N1: 50 kg/ha; N2: $100 \mathrm{~kg} / \mathrm{ha}$; dan N3: $150 \mathrm{~kg} / \mathrm{ha}$. E0: kontrol (tanpa ethephon); E1= $100 \mathrm{mg} / \mathrm{l}, \mathrm{E} 2=200 \mathrm{mg} / \mathrm{l}$, dan E3= $400 \mathrm{mg} / \mathrm{l}$.

Tabel 1. Karakter fisiologi tanaman padi rojolele setelah perlakuan pupuk nitrogen dan ethephon pada dosis yang berbeda.

\begin{tabular}{|c|c|c|c|c|c|c|c|c|c|c|}
\hline \multirow{2}{*}{ Pelakuan } & \multirow{2}{*}{$\begin{array}{c}\text { Tinggi Tanaman } \\
(\mathrm{cm})\end{array}$} & \multirow{2}{*}{\multicolumn{2}{|c|}{$\begin{array}{c}\text { Jumlah } \\
\text { daun }\end{array}$}} & \multirow{2}{*}{$\begin{array}{l}\text { Jumlah } \\
\text { anakan } \\
\end{array}$} & \multicolumn{2}{|c|}{ Bobot segar (g) } & \multirow{2}{*}{$\begin{array}{c}\text { Rasio } \\
\text { Akar/tajuk }\end{array}$} & \multicolumn{2}{|c|}{ Bobot kering (g) } & \multirow{2}{*}{$\begin{array}{c}\text { Rasio } \\
\text { Akar/Tajuk }\end{array}$} \\
\hline & & & & & Akar & Tajuk & & Akar & Tajuk & \\
\hline "NOE0 & $168,50^{\mathrm{a}}$ & 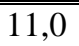 & 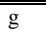 & $\overline{c 1,4^{\mathrm{ab}}}$ & $4,17^{\mathrm{a}}$ & $\overline{770,00^{a}}$ & $0,059^{\mathrm{a}}$ & $1,63^{\mathrm{a}}$ & $20,97^{a}$ & $0,082^{a}$ \\
\hline NOE1 & $165,56^{\mathrm{ab}}$ & 9,8 & $\mathrm{~g}$ & $1,2^{\mathrm{a}}$ & $5,17^{\mathrm{a}}$ & $59,67^{\mathrm{a}}$ & $0,087^{\mathrm{ab}}$ & $1,90^{\mathrm{ab}}$ & $21,31^{\mathrm{a}}$ & $0,089^{a}$ \\
\hline NOE2 & $147,60^{\text {bcde }}$ & 10,2 & $\mathrm{~g}$ & $1,4^{\mathrm{ab}}$ & $4,67^{\mathrm{a}}$ & $57,67^{\mathrm{a}}$ & $0,082^{\mathrm{ab}}$ & $2,13^{\mathrm{ab}}$ & $19,30^{\mathrm{a}}$ & $0,112^{a}$ \\
\hline N0E3 & $135,62^{\mathrm{def}}$ & 10,8 & $\mathrm{~g}$ & $1,4^{\mathrm{ab}}$ & $6,17^{\mathrm{a}}$ & $58,00^{\mathrm{a}}$ & $0,110^{\mathrm{abc}}$ & $2,66^{\mathrm{ab}}$ & $20,15^{\mathrm{a}}$ & $0,147^{a b}$ \\
\hline N1E0 & $168,44^{\mathrm{a}}$ & 16,8 & f & $2,0^{a b c}$ & $10,67^{\mathrm{ab}}$ & $106,67^{b c d}$ & $0,100^{\mathrm{abc}}$ & $5,33^{\mathrm{ab}}$ & $36,25^{b c}$ & 0,147 ab \\
\hline N1E1 & $161,06^{\mathrm{ab}}$ & 16,8 & f & $2,4^{b c}$ & $11,50^{\mathrm{abc}}$ & $97,00^{b c}$ & $0,131^{\mathrm{abcd}}$ & $5,96^{\mathrm{b}}$ & $34,44^{b}$ & $0,179^{a b c}$ \\
\hline N1E2 & $153,36^{\mathrm{abcd}}$ & 18,4 & ef & $2,6^{\mathrm{cd}}$ & $11,83^{\mathrm{abc}}$ & $100,00^{\mathrm{bc}}$ & $0,118^{a b c}$ & $5,80^{\mathrm{b}}$ & $34,62^{b}$ & $0,172 a b$ \\
\hline N1E3 & $140,96^{\text {cdef }}$ & 17,8 & f & & $12,50^{\mathrm{abc}}$ & $93,67^{b}$ & $0,126^{\mathrm{abc}}$ & $5,16^{\mathrm{ab}}$ & $33,55^{b}$ & $0,153^{a b}$ \\
\hline N2E0 & $164,82^{\mathrm{ab}}$ & 22,8 & $\mathrm{~cd}$ & 3,8 ef & $28,50^{\mathrm{de}}$ & $137,67^{\mathrm{e}}$ & $0,207^{\text {efg }}$ & $14,43^{\mathrm{de}}$ & 46,92 ef & $0,305 \mathrm{de}$ \\
\hline N2E1 & $168,10^{\mathrm{a}}$ & 23,4 & $\mathrm{~cd}$ & 3,6 de & $20,17^{\mathrm{bcd}}$ & $134,00^{\mathrm{e}}$ & $0,148^{\text {bcde }}$ & $11,50^{\mathrm{cd}}$ & 47,06 ef & 0,249 bcd \\
\hline N2E2 & $142,88^{\text {cdef }}$ & 25,0 & bcd & $4,6^{\text {ef }}$ & $20,67^{\mathrm{cd}}$ & $122,67^{\mathrm{de}}$ & $0,172^{\text {cdef }}$ & $9,67^{\mathrm{c}}$ & $39,63 \mathrm{bcd}$ & 0,244 bcd \\
\hline N2E3 & $129,34^{\mathrm{f}}$ & 24,4 & bcd & $4,8 \mathrm{fg}$ & $25,67^{\mathrm{de}}$ & $113,67^{\mathrm{cd}}$ & $0,228^{\mathrm{fg}}$ & $13,16^{\text {cde }}$ & $40,60^{\text {bcde }}$ & $0,324 \mathrm{de}$ \\
\hline N3E0 & $157,12^{\mathrm{abc}}$ & 28,2 & $a b c$ & $6,0^{\mathrm{h}}$ & $38,67^{\mathrm{f}}$ & $157,00^{f}$ & $0,247^{\mathrm{g}}$ & $15,70^{\mathrm{e}}$ & $56,40^{\mathrm{g}}$ & $0,279^{\mathrm{cd}}$ \\
\hline N3E1 & $150,50^{\text {abcde }}$ & 28,4 & $\mathrm{ab}$ & $5,8^{\mathrm{gh}}$ & $32,00^{\mathrm{ef}}$ & $158,33^{f}$ & $0,200^{\text {defg }}$ & $15,16^{\mathrm{de}}$ & $53,45^{\mathrm{fg}}$ & $0,285^{\mathrm{d}}$ \\
\hline N3E2 & $134,04^{e f}$ & 31,6 & a & $6,6^{\mathrm{h}}$ & $28,67^{\mathrm{de}}$ & $135,00^{\mathrm{e}}$ & $0,213^{\text {efg }}$ & $11,33^{\mathrm{cd}}$ & $45,33^{\mathrm{de}}$ & 0,245 bcd \\
\hline N3E3 & $125,94^{\mathrm{f}}$ & 28,6 & $\mathrm{ab}$ & $6,4^{\mathrm{h}}$ & $33,00^{\mathrm{ef}}$ & $122,33^{\mathrm{de}}$ & $0,266^{\mathrm{g}}$ & $16,16^{\mathrm{e}}$ & $42,21^{\mathrm{cde}}$ & $0,385^{\mathrm{e}}$ \\
\hline
\end{tabular}

Keterangan: Angka-angka yang diikuti huruf sama pada kolom yang sama tidak berbeda nyata dengan uji Duncan pada taraf 0.05 . 
Tabel 1 memperlihatkan peningkatan jumlah daun dan jumlah anakan, sejalan dengan meningkatnya dosis nitrogen yang diberikan berkorelasi positif dengan berat segar tajuk. Adapun ethephon menunjukkan pengaruh sebaliknya, semakin tinggi dosis ethephon yang diberikan, semakin rendah berat segar tajuk tanaman. Hal ini berkaitan efek pemberian ethephon yang menurunkan fotosintesis dengan peningkatan level etilen yang merupakan hormon alami untuk menghambat pertumbuhan (Davies, 1995). Pertumbuhan tinggi tanaman terhambat, tentunya berakibat menurunkan berat segar tajuk. Peningkatan jumlah daun dan berat tajuk karena nutrien nitrogen yang memadai. Hal ini dijelaskan berkaitan dengan peningkatan kapasitas untuk mengambil nutrien oleh tanaman dan peningkatan translokasi karbohidrat dari sumber ke titik tumbuh (Chaturvedi, 2005). Pertumbuhan tanaman dipengaruhi faktor lingkungan terutama ketersediaan nutrisi. Pada penelitian ini, pemupukan nitrogen pada dosis yang tepat dapat meningkatkan pertumbuhan dan produktivitas tanaman padi. Pemberian pupuk nitrogen pada dosis $150 \mathrm{~kg} / \mathrm{ha}$ menyebabkan tanaman padi kultivar Rojolele membentuk anakan lebih banyak daripada tanaman dengan dosis pupuk nitrogen lebih rendah.

Berdasarkan hasil yang diperoleh, diketahui bahwa berat kering tajuk memiliki hubungan yang linier dengan berat segar tajuk. Terpenuhinya kebutuhan hara $\mathrm{N}$ meningkatkan pertumbuhan vegetatif, dengan demikian jumlah daun meningkat dan hasil fotosintesis meningkat sehingga berat kering tajuk meningkat sejalan dengan penambahan pemberian dosis $\mathrm{N}$. Sementara itu, berat kering tajuk pada perlakuan ethephon menurun seiring dengan meningkatnya konsentrasi yang diberikan. Efek ethephon terhadap penurunan nilai berat kering tajuk sesuai dengan pengaruhnya yang menghambat pertumbuhan tinggi tanaman (Straub, 1989; Tripathi et al., 2003). Dengan terhambatnya pertumbuhan tinggi tanaman menyebabkan berat kering tajuk menurun sehingga pertambahan biomassa tanaman menurun.

Rasio akar-tajuk dibuat untuk mengetahui hubungan akar dan tajuk. Rasio akar-tajuk merupakan sifat yang sangat plastis (Fitter dan Hay, 2002). Dari hasil penelitian diketahui bahwa perlakuan nitrogen memberikan pengaruh beda nyata terhadap rasio akar-tajuk. Dapat dilihat dari hasil rerata rasio akar-tajuk (Tabel 1), semakin tinggi dosis $\mathrm{N}$ yang diberikan semakin tinggi nilai rasio akar-tajuk. Hal ini menunjukkan bahwa semakin banyak $\mathrm{N}$ yang dapat diserap oleh akar maka semakin banyak nutrien yang diperoleh daun untuk aktivitas metabolismenya. Akibatnya fotosintat yang dihasilkan menjadi besar. Fotosintat ini akan ditransfer dari daun ke bagian organ tanaman yang lain termasuk akar. Akumulasi fotosintat di akar menjadi besar, sehingga rasio akar-tajuk menjadi besar. Pemberian ethephon mempunyai pengaruh nyata terhadap rasio akar-tajuk pada padi. Hal ini diduga ethephon memberikan efek pada pertumbuhan vegetatif tanaman padi (Rajala dan Peltonen-Sainio, 2001). Ethephon merupakan zat pengatur tumbuh yang efeknya mampu menghambat atau memacu pertumbuhan tanaman, tetapi efek tersebut tergantung pada jenis tanaman, dosis dan waktu pemberian perlakuan (Arshad dan Frankenberger, 2002). Rasio akar-tajuk berhubungan dengan efektivitas pertumbuhan tanaman. Rasio akar tajuk adalah korelasi pertumbuhan yang merupakan perbandingan akar dan tajuk tanaman dengan maksud mengetahui tingkat kesuburan tanah. Peningkatan jumlah nitrogen memengaruhi pertumbuhan tajuk yang memungkinkan adanya penggunaan karbohidrat yang tersedia. Adanya nitrogen yang cukup untuk tanaman mendorong pertumbuhan vegetatif bagian diatas tanah, meningkatkan rasio akar/tajuk, dan esensial untuk pembentukan buah dan biji.

Klorofil merupakan komponen yang dapat berubah kuantitasnya karena pengaruh faktor eksternal. Peningkatan kandungan klorofil a dan b pada perlakuan nitrogen menyebabkan peningkatan kemampuan menangkap energi cahaya untuk proses fotosintesis. Hasil ANAVA dan uji DMRT taraf signifikansi 5\% (Tabel 2) kandungan klorofil a dan $b$ daun tanaman padi varietas rojolele menunjukkan adanya peningkatan kadar klorofil a dan $b$ sejalan dengan peningkatan dosis nitrogen yang diberikan. Namun, perlakuan pemberian ethephon dan interaksi antara nitrogen dan ethephon tidak menunjukkan pengaruh beda nyata. Peningkatan kadar klorofil daun akibat pemberian pupuk urea, terjadi karena kebutuhan $\mathrm{N}$ yang mutlak diperlukan sebagai komponen 
dalam biosintesis klorofil terpenuhi. Menurut Below (2002) peningkatan suplai nitrogen meningkatkan pertumbuhan, komposisi $\mathrm{N}$ dan klorofil serta kapasitas fotosintesis daun. Telah diketahui bahwa nitrogen memengaruhi kandungan pigmen fotosintesis, sintesis enzim yang berperan dalam reduksi karbon, pembentukan sistem membran kloroplas, dll. Dengan demikian peningkatan pertumbuhan dan hasil, disebabkan oleh nitrogen adalah komponen dari nukleotida, protein, klorofil dan enzim, yang terlibat dalam berbagai proses metabolisme dan berdampak langsung pada fase vegetatif dan reproduksi tanaman (Barker dan Pilbeam, 2007; Mangunwardoyo et al., 2009).

\section{Pembungaan}

Fase reproduktif suatu tanaman ditandai dengan munculnya kuncup bunga. Pada penelitian ini untuk mengetahui waktu pembungaan tanaman padi Rojolele, dilihat dengan waktu awal tanaman berbunga (Tabel 3).
Waktu pembungaan dihitung sejak bunga pertama kali keluar untuk tiap-tiap perlakuan. Berdasarkan data yang disajikan Tabel 3, menunjukkan semakin tinggi dosis pupuk nitrogen dan ethephon yang diberikan semakin lama tanaman berbunga. Pembungaan tanaman pada perlakuan nitrogen dengan ethephon pada dosis $400 \mathrm{mg} \mathrm{l}^{-1}$ lebih lambat dibandingkan perlakuan dosis ethephon yang lebih rendah. Pemupukan nitrogen yang tinggi akan memicu pertumbuhan tanaman lebih baik dan jumlah anakan lebih banyak. Namun jumlah anakan yang banyak menyebabkan terjadinya kompetisi nutrisi sehingga berpengaruh pada kemampuannya dalam membentuk bunga. Hal ini terlihat pada hasil pengamatan perlakuan pupuk nitrogen $150 \mathrm{~kg} \mathrm{~N} / \mathrm{ha}$ menunjukkan waktu pembungaan yang lebih lambat. Pasokan nitrogen yang cukup pada tanaman selama periode pertumbuhan awal sangat penting untuk inisiasi daun dan primordia bunga.

Tabel 2. Kandungan klorofil a dan b daun padi Rojolele setelah perlakuan pemberian nitrogen dan ethephon.

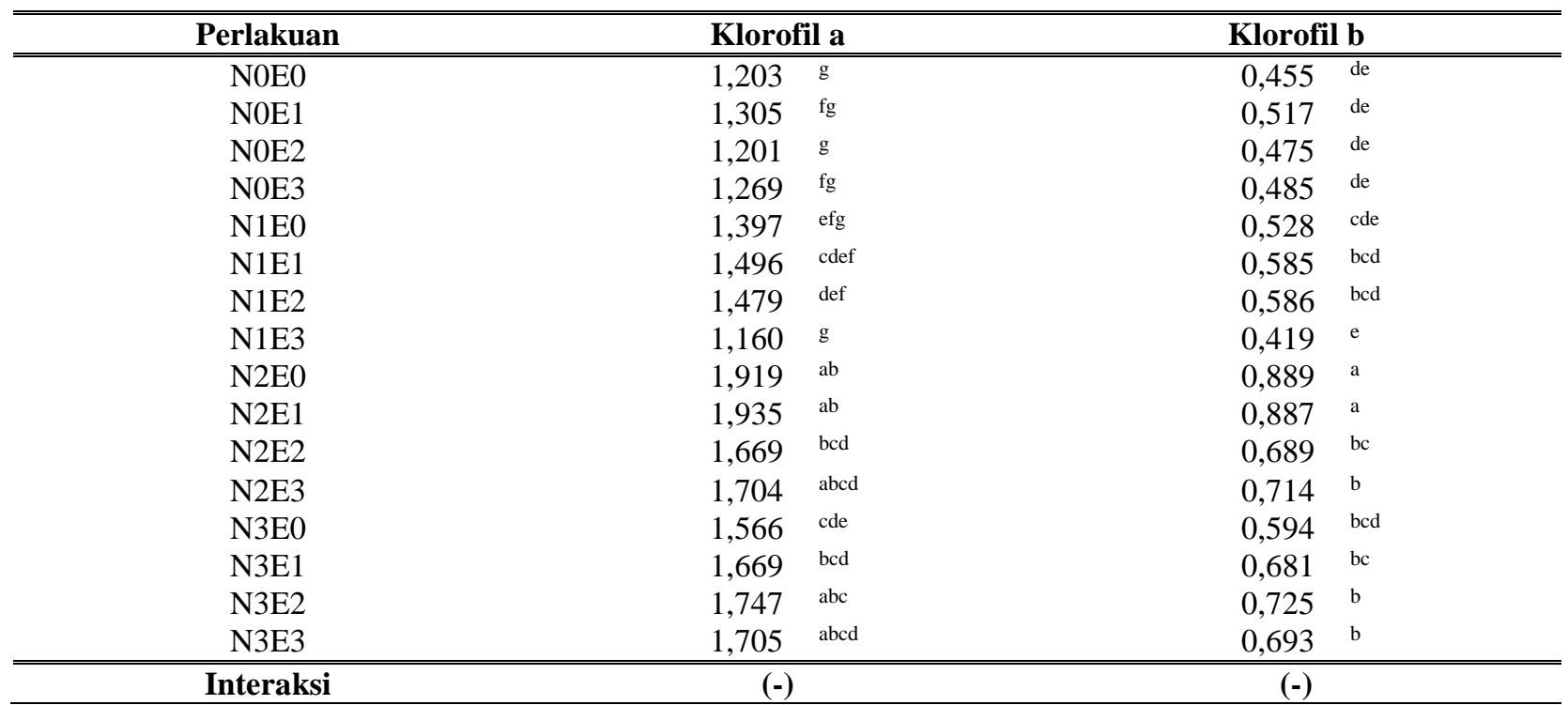

Keterangan: angka yang diikuti oleh huruf yang sama pada kolom menunjukkan tidak ada beda nyata pada DMRT taraf $5 \%$.

Tabel 3. Waktu pembungaan pertama (hari setelah tanam) padi (Oryza sativa L. cv. Rojolele) pada perlakuan pupuk nitrogen dan ethephon.

\begin{tabular}{ccccc}
\hline \hline \multirow{2}{*}{ Ethephon } & \multicolumn{4}{c}{ Pupuk Nitrogen } \\
\cline { 2 - 5 } & N0 & N1 & N2 & N3 \\
\hline \hline E0 & 113 & 110 & 112 & 110 \\
E1 & 122 & 118 & 114 & 124 \\
E2 & 120 & 119 & 125 & 128 \\
E3 & 126 & 129 & 134 & 140 \\
\hline \hline
\end{tabular}


Pada dosis $\mathrm{N}$ yang semakin tinggi, waktu berbunga semakin lama. Hal ini kemungkinan disebabkan karena adanya unsur $\mathrm{N}$ yang cukup atau berlebih menyebabkan pertumbuhan vegetatif tanaman meningkat, jumlah daun dan jumlah anakan meningkat sehingga untuk berbunga membutuhkan waktu yang lebih lama daripada kontrol. Namun pengaruh pemupukan nitrogen terhadap waktu pembungaan padi lokal rojolele ini tidak dapat terlepas karena adanya pengaruh ethephon. Pemberian ethephon tampaknya berpengaruh pada waktu pembungaan, pada perlakuan ethephon dosis 400 $\mathrm{mg} \mathrm{l}^{-1}$ menyebabkan waktu pembungaan lebih lama. Selain itu, pada perlakuan ethephon tanaman menjadi lebih pendek dibandingkan dengan kontrol. Aplikasi ethephon pada tanaman akan menghasilkan etilen. Di duga, etilen ini akan mengurangi kemampuan auksin tanaman untuk memacu pertumbuhan batang dan menyebabkan tanaman menjadi lebih pendek. Efek ethephon berbeda-beda pada setiap jenis tanaman (Davies, 1995). Dari penelitian ini diketahui ethephon tidak dapat mempercepat masa berbunga tanaman padi varietas rojolele, sebaliknya justru bersifat menunda waktu berbunga dengan memperpanjang fase pertumbuhan vegetatif tanaman. Masa vegetatif tanaman padi rojolele lebih panjang jika dibandingkan dengan padi varietas lain. Dalam penelitian ini, fase vegetatif padi rojolele berlangsung sekitar 14 minggu, kemudian tanaman mengalami fase peralihan dari fase vegetatif menuju generatif sampai minggu ke 16 dan selanjutnya pada minggu ini beberapa tanaman mulai berbunga.

Hasil penelitian juga memperlihatkan bahwa dosis $\mathrm{N}$ semakin tinggi maka waktu berbunga semakin lama. Hal ini kemungkinan disebabkan oleh adanya unsur $\mathrm{N}$ yang cukup sehingga pertumbuhan vegetatif tanaman meningkat, jumlah daun meningkat dan jumlah anakan meningkat sehingga untuk berbunga membutuhkan waktu yang lebih lama dari pada kontrol. Namun pengaruh $\mathrm{N}$ terhadap waktu pembungaan padi Rojolele ini tidak dapat terlepas dari adanya pengaruh ethephon. Ethephon adalah zat pengatur tumbuh yang dapat membebaskan etilen saat diberikan pada tanaman. Seperti yang telah di ketahui bahwa etilen adalah hormon yang dapat menghambat pertumbuhan (Davies, 1995; Srivastava, 2002). Pemberian ethephon ternyata mampu menghambat pertumbuhan batang yang artinya ethephon menghambat fase pertumbuhan vegetatif. Jika dilihat efek ethephon dari beberapa paremeter pertumbuhan di atas, diduga ethephon bukan mempersingkat fase vegetatif tanaman padi kultivar Rojolele melainkan hanya bersifat menghambat atau menunda. Artinya semakin tinggi dosis ethephon yang diberikan maka semakin terhambat pertumbuhan tanaman padi dan semakin lama tanaman tersebut memasuki fase reproduktif, tentu saja dengan kenaikan dosis $\mathrm{N}$ juga semakin memperlama tanaman memasuki waktu berbunga karena $\mathrm{N}$ tinggi akan menggiatkan atau meningkatkan pertumbuhan vegetatif tanaman.

\section{Hasil Panen Padi Rojolele}

Nitrogen mendorong pertumbuhan tanaman, memperbaiki tingkat hasil dan kualitas biji melalui peningkatan jumlah anakan, pembentukan gabah, pengisian gabah dan sintesis protein. Pemberian pupuk nitrogen yang cukup dapat menghasilkan mutu fisik gabah yang lebih baik karena unsur $\mathrm{N}$ memberikan kontribusi terhadap jumlah biji yang terbentuk (Chaturvedi, 2005). Kualitas padi tidak hanya ditentukan secara genetik tetapi juga dipengaruhi oleh faktor lingkungan (Mew dan Misra, 1994).

Pemberian nitrogen dan ethephon juga berpengaruh terhadap hasil padi yang dilihat dari jumlah gabah yang dihasilkan dari tiap malai (Tabel 4). Dari hasil pengamatan terdapat korelasi positif antara panjang malai dan jumlah biji per malai. Panjang malai terendah $24,50 \mathrm{~cm}$ dan tertinggi $36,32 \mathrm{~cm}$, sedangkan jumlah gabah bernas terendah 78 butir dan tertinggi 153 butir. Panjang malai dan jumlah gabah isi per malai sangat menentukan hasil panen. Makin panjang malai, jumlah gabah yang dihasilkan juga makin banyak. Jumlah gabah bernas per malai sangat ditentukan oleh faktor pemupukan. Pemupukan $\mathrm{N}$ tanpa diimbangi dengan pupuk $\mathrm{P}$ dan $\mathrm{K}$ akan mendorong dihasilkannya gabah hampa dengan persentase tinggi. Hasil penelitian menunjukkan bahwa hasil gabah tampaknya dipengaruhi oleh pupuk $\mathrm{N}$ yang diberikan dan interaksi antara pupuk $\mathrm{N}$ dan ethephon. Aplikasi nitrogen dapat meningkatkan jumlah gabah per malai (Maqsood et al., 2000). Hasil yang serupa juga 
dilaporkan Tripathi et al., (2003) ethephon dapat meningkatkan hasil gandum karena pengaruhnya dalam meningkatkan ketahanan rebah.

Biji padi dipanen setelah matang secara fisiologis yang dicirikan dengan warna gabah kuning. Diketahui bahwa sejalan dengan proses pemasakan biji kadar air di dalam biji semakin menurun. Dari hasil pengamatan terlihat adanya perbedaan kadar air biji dimungkinkan karena tingkat kemasakan biji yang dipanen tidak seragam. Perlakuan ethephon menyebabkan umur pembungaan lebih lama dan berakibat umur panen juga lebih lama. Hasil panen menunjukkan bahwa jumlah biji yang dihasilkan setiap tanaman menunjukkan perbedaan antarperlakuan dengan persentase biji hampa kurang dari 20\%. Sementara itu, berat 1000 butir gabah tidak berbeda nyata antarperlakuan. Berat rata-rata biji dari setiap perlakuan berkisar antara 29,52 - 32,33 g per 1000 butir (Tabel 4).

Ketersediaan hara yang optimal memberikan kontribusi pada pertumbuhan tanaman dan hasil biji. Varietas padi dapat diklasifikasikan ke dalam kategori tipe biji berdasarkan pada 2 parameter fisik biji yaitu ukuran dan bentuk biji. Besar kecilnya ukuran gabah ditentukan oleh faktor tingkat kesuburan tanah di samping sifat genetis. Pemberian pupuk nitrogen yang cukup dapat menghasilkan mutu fisik gabah yang lebih baik karena unsur $\mathrm{N}$ memberikan kontribusi terhadap jumlah biji yang terbentuk (Chaturvedi, 2005). Pupuk N yang diberikan tidak berpengaruh nyata terhadap ukuran biji padi rojolele. Diketahui bentuk biji padi bersifat khas untuk tiap spesies tanaman, sedangkan berat biji merupakan sifat yang dikendalikan secara genetik dan dipengaruhi oleh lingkungan selama proses pengisian biji (Kausar et al., 1993).

Perlakuan pemupukan nitrogen dan ethephon tidak berpengaruh nyata terhadap ukuran gabah rojolele (Tabel 5). Dari perlakuan diperoleh hasil, panjang gabah berkisar $(9,00-$ $9,31) \mathrm{mm}$ dengan rata-rata $(9,12 \pm 0,074) \mathrm{mm}$, lebar gabah berkisar $(3,06-3,22) \mathrm{mm}$ dengan rata-rata $(3,11 \pm 0,039) \mathrm{mm}$. Perbandingan antara panjang dibagi lebar gabah menghasilkan bentuk gabah medium dan kisaran panjang per lebar $(2,88-2,96)$ dan rata-rata 2,93 (Tabel 5). Berdasarkan bentuk bijinya rojolele memliki bentuk medium. Klasifikasi bentuk biji sebagai berikut langsing $(>3,0)$, medium $(2,1-3,0)$ dan bulat (2,0 atau kurang dari 2,0) (Graham, 2002). Selain itu, beras rojolele memiliki ciri spesifik yaitu adanya noda putih di perut. Ciri tersebut dapat digunakan untuk mengetahui tingkat kemurnian gabah rojolele (Mudjisihono et al., 2002).

Tabel 4. Pengaruh pupuk nitrogen dan ethephon terhadap hasil padi rojelele.

\begin{tabular}{|c|c|c|c|c|}
\hline Perlakuan & Panjang Malai (cm) & $\sum$ gabah per malai & $\begin{array}{c}\text { Persen Gabah } \\
\text { Hampa per Malai }\end{array}$ & $\begin{array}{c}\text { Bobot } 1000 \\
\text { Butir Gabah }(\mathrm{g}) \\
\end{array}$ \\
\hline "NOE0 & $34,86^{\mathrm{ab}}$ & $152,6^{\text {abcd }}$ & $14,19^{\mathrm{a}}$ & $31,83^{\mathrm{a}}$ \\
\hline NOE1 & $32,50 \mathrm{bcd}$ & $126,8^{\text {cdefg }}$ & 9,45 ab & $31,65^{\mathrm{a}}$ \\
\hline NOE2 & $30,35^{\mathrm{d}}$ & $121,5^{\operatorname{defg}}$ & $8,20^{a}$ & $31,40^{\mathrm{a}}$ \\
\hline NOE3 & $33,87^{a b c}$ & $146,0^{\mathrm{ab}}$ & 14,38 a & $30,53^{\mathrm{a}}$ \\
\hline N1E0 & $36,32^{a}$ & $178,8^{\mathrm{a}}$ & $12,57^{a}$ & $29,52^{\mathrm{a}}$ \\
\hline N1E1 & $33,30^{a b c}$ & $136,8^{\text {bcde }}$ & 10,37 a & $32,33^{\mathrm{a}}$ \\
\hline N1E2 & $30,52^{d}$ & $118,8^{\text {defg }}$ & 16,33 a & $30,40^{\mathrm{a}}$ \\
\hline N1E3 & 32,44 bcd & $122,8^{\text {defg }}$ & 13,52 a & $30,91^{\mathrm{a}}$ \\
\hline $\mathrm{N} 2 \mathrm{E} 0$ & $35,73^{\mathrm{a}}$ & $161,2^{\mathrm{abc}}$ & $16,98^{a}$ & $30,95^{\mathrm{a}}$ \\
\hline $\mathrm{N} 2 \mathrm{E} 1$ & $35,25^{\mathrm{ab}}$ & $147,2^{\text {abcde }}$ & 14,12 a & $30,37^{\mathrm{a}}$ \\
\hline $\mathrm{N} 2 \mathrm{E} 2$ & 30,68 de & $103,5^{\mathrm{fg}}$ & 17,07 a & $30,98^{a}$ \\
\hline N2E3 & 28,85 ef & $95,0^{\mathrm{g}}$ & $15,79^{a}$ & $29,75^{\mathrm{a}}$ \\
\hline N3E0 & $34,45^{a b c}$ & $166,5^{\mathrm{ab}}$ & $11,71^{\text {a }}$ & $31,51^{\mathrm{a}}$ \\
\hline N3E1 & $25,25^{\mathrm{f}}$ & $115,0^{\text {efg }}$ & 17,39 a & $31,67^{\mathrm{a}}$ \\
\hline N3E2 & $24,50^{\mathrm{f}}$ & $110,0^{\text {efg }}$ & $15,45^{a}$ & $30,77^{\mathrm{a}}$ \\
\hline N3E3 & $25,30^{f}$ & $94,5^{\mathrm{g}}$ & 17,89 b & $30,60^{\mathrm{a}}$ \\
\hline
\end{tabular}

Keterangan: Angka-angka yang diikuti huruf sama pada kolom yang sama tidak berbeda nyata dengan uji Duncan pada taraf 0.05 . 
Tabel 5. Data analisis panjang, lebar, bentuk dan kriteria mutu gabah hasil panen padi rojelele setelah perlakuan pupuk nitrogen dan ethephon.

\begin{tabular}{|c|c|c|c|c|}
\hline Perlakuan & Panjang (mm) & Lebar (mm) & Bentuk (P/L) & $\begin{array}{l}\left.\text { Kriteria }^{*}\right) \\
\end{array}$ \\
\hline NOE0 & $9,11 \pm 0,113$ & $3,09 \pm 0,097$ & 2,95 & Medium \\
\hline N0E1 & $9,09 \pm 0,085$ & $3,07 \pm 0,113$ & 2,96 & Medium \\
\hline NOE2 & $9,31 \pm 0,198$ & $3,22 \pm 0,100$ & 2,89 & Medium \\
\hline NOE3 & $9,12 \pm 0,181$ & $3,17 \pm 0,109$ & 2,88 & Medium \\
\hline N1E0 & $9,06 \pm 0,146$ & $3,09 \pm 0,070$ & 2,93 & Medium \\
\hline N1E1 & $9,14 \pm 0,151$ & $3,12 \pm 0,094$ & 2,93 & Medium \\
\hline N1E2 & $9,06 \pm 0,163$ & $3,12 \pm 0,103$ & 2,91 & Medium \\
\hline N1E3 & $9,11 \pm 0,227$ & $3,16 \pm 0,089$ & 2,88 & Medium \\
\hline $\mathrm{N} 2 \mathrm{E} 0$ & $9,15 \pm 0,137$ & $3,10 \pm 0,083$ & 2,95 & Medium \\
\hline N2E1 & $9,15 \pm 0,131$ & $3,09 \pm 0,095$ & 2,96 & Medium \\
\hline N2E2 & $9,10 \pm 0,105$ & $3,10 \pm 0,081$ & 2,94 & Medium \\
\hline N2E3 & $9,00 \pm 0,109$ & $3,06 \pm 0,083$ & 2,94 & Medium \\
\hline N3E0 & $9,18 \pm 0,075$ & $3,14 \pm 0,136$ & 2,92 & Medium \\
\hline N3E1 & $9,00 \pm 0,171$ & $3,11 \pm 0,136$ & 2,89 & Medium \\
\hline N3E2 & $9,08 \pm 0,228$ & $3,08 \pm 0,109$ & 2,95 & Medium \\
\hline N3E3 & $9,05 \pm 0,134$ & $3,10 \pm 0,129$ & 2,92 & Medium \\
\hline
\end{tabular}

${ }^{\left.{ }^{*}\right)}$ Klasifikasi bentuk biji: langsing ( > 3,0), medium (2,1-3,0) dan bulat (2,0 atau kurang dari 2,0) (Graham, 2002).

\section{Simpulan dan Saran}

\section{Simpulan}

Pemberian pupuk nitrogen meningkatkan pertumbuhan tanaman padi kultivar rojolele. Jumlah anakan, biomassa tanaman dan jumlah gabah bernas meningkat dengan meningkatnya dosis pupuk nitrogen. Namun pupuk nitrogen tidak berpengaruh nyata pada kualitas fisik biji. Perlakuan ethephon secara signifikan menurunkan tinggi tanaman. Kombinasi pupuk nitrogen dan ethephon menunjukkan pengaruh yang nyata pada pertumbuhan tanaman dan jumlah gabah per malai tetapi tidak berpengaruh terhadap kualitas fisik biji padi rojolele.

\section{Saran}

Dalam upaya untuk meningkatkan produktivitas tanaman padi lokal rojolele perlu dilakukan kajian lebih lanjut mengenai dosis dan waktu aplikasi pupuk dan zat pengatur tumbuh yang tepat untuk memperpendek masa vegetatif dan atau mempercepat waktu pembungaannya.

\section{Ucapan Terima Kasih}

Penelitian ini dibiayai melalui program penelitian fundamental tahun anggaran 2007 dari DP2M-DIKTI. Ucapan terima kasih penulis sampaikan kepada Pengelola Kebun Pendidikan, Penelitian dan Pengembangan Pertanian (KP4) UGM atas kerja samanya selama pelaksanaan penelitian ini.

\section{Daftar Pustaka}

Arshad, M. dan Frankenberger Jr, W.T. 2002. Ethylene: Agricultural Sources and Applications. Kluwer Academic/Plenum Publ., New York.

Atmodjo, K. 2000. Penggunaan Tulang dan Kulit Nanas sebagai Pupuk Organik untuk Menumbuhkan Sawi (Brassica Juncea L.). Biota, V (2): 63-70.

Below, F.E. 2002. Nitrogen Metabolism and Crop Productivity Second Edition. In: Pessarakli, M. (Eds.). Handbook of Plant and Crop Physiology. Marcel Dekker, Inc. New York.

Barker, A.V. dan Pilbeam, D.J. 2007. Handbook of Plant Nutrition. CRC Press. Taylor \& Francis Group. Boca Raton London New York. 
Chaturvedi, I. 2005. Effect of Nitrogen Fertilizer on Growth, Yield and Quality of Hybrid Rice (Oryza sativa). J. of Central European Agriculture, 6 (4): 611-618.

Davies, P.J. 1995. Plant Hormone: Physiology, Biochemistry and Molecular Biology. Kluwer Academic Publishers. Dordrecht, Boston, London.

De Datta, S.K. 1981. Principle and Practies of Rice Production. John Wiley and Sons. New York.

Fitter, A. dan Hay, R.K.M. 2002. Environmental Physiology of Plant. Third Edition. Academic Press. UK.

Graham, R. 2002. A Proposal for IRRI to Establish a Grain Quality and Nutrition Research Center. IRRI Discussion Paper Series No. 44. International Rice Research Institute. Los Baños Philippines.

Gomez, K.A. dan Gomez, A.A. 1984. Statistical Procedures for Agricultural Research $2^{\text {nd }}$ edition. John Wiley \& Sons, Inc. New York.

Hazarika dan Sarkar, M.C. 1996. Effect of Integrated N Management on The Recovery of Fertilizer N by Rice (Oryza sativa L.). J. Nuclear Agri. Biol., 25: 32-37.

Kausar, K., Akbar, M., Rasul, E. dan Ahmad, A.N. 1993. Physiological Responses of Nitrogen, Phosphorus and Potassium on Growth and Yield of Wheat. Pak. J. Agric. Res., 14: 2-3.

Mangunwardoyo, W., Lusini, Y. dan Gandjar, I. 2009. Karakterisasi, Pengaruh Sumber Nitrogen dan Karbon terhadap Produktivitas Enzim Lipase Rhizopus microsporus var oligosporus UICC 550. Biota, 14 (2): 115-124.

Maqsood, M., Irshad, M., Hussain, M.I. dan Rafiq, K. 2000. Effect of Nitrogen on Growth, Yield and Quality of Fine Rice. J. of Biological Sciences, 3 (11): 1831-1832.

Mew, T.W. dan Misra, J.K. 1994. A Manual of Rice Seed Health Testing. International Rice Research Institute. Los Baños, Laguna, Philippines.
Mudjisihono, R., Santosa, T. dan Hendrata, R. 2002. Laporan Hasil Pengkajian Uji Varietas Rojolele Kabupaten Klaten. Balai Pengkajian Teknologi Pertanian Yogyakarta.

Rademacher, W. 2000. Growth Retardant: Effects on Gibberelin Biosynthesis and Other Metabolic Pathways. Annual Review of Plant Physiology and Plant Molecular Biology, 51: 501-531.

Rajala, A. dan Peltonen-Sainio, P. 2001. Plant Growth Regulator Effects on Spring Cereal Root and Shoot Growth. Agronomy J., 93: 936-943.

Srivastava, L.M. 2001. Plant Growth and Development Hormon and Environment. Academic Press. San Diego, California, USA.

Setyorini, D. dan Abdulrachman, S. 2008. Pengelolaan Hara Mineral Tanaman Padi. In Padi-Inovasi Teknologi dan Ketahanan Pangan Buku I. Balai Besar Penelitian Tanaman Padi. Badan Penelitian dan Pengembangan Pertanian.

Straub, R.W. 1989. Ethephon growth regulator as a potential tool for managing excessive height in sweet corn hybrids. New York's Food and Life Sciences Bull., 129: 1-4.

Tripathi, S.C., Sayre, K.D., Kaul, J.N. dan Narang, R.S. 2003. Lodging behaviour and yield potential of spring wheat (Triticum aestivum L.): effects of ethephon and genotypes. Field Crop Research, 87: 207-220.

Utami, N.W. 2005. Pertumbuhan Kaempferia rotunda L. dengan Perlakuan Variasi Jumlah Umbi Semu dan Penambahan Pupuk Organik. Biota, X (1): 36-42.

Woodward, E.J. dan Marshall, C. 1987. Effects of seed treatment with plant growth regulator on growth and tillering in spring barley (Hordeum distichum cv. Triumph). Ann.Appl.Biol., 110: 629-638. 